\title{
Prevalence of arterial hypertension and risk factors in adolescents
}

\section{Prevalência de hipertensão arterial e seus fatores de risco em adolescentes}

\author{
Ionara Holanda de Moura ${ }^{1}$ \\ Eduardo Emanuel Sátiro Vieira ${ }^{1}$ \\ Grazielle Roberta Freitas da Silva ${ }^{1}$ \\ Rumão Batista Nunes de Carvalho ${ }^{1}$ \\ Ana Roberta Vilarouca da Silva ${ }^{1}$
}

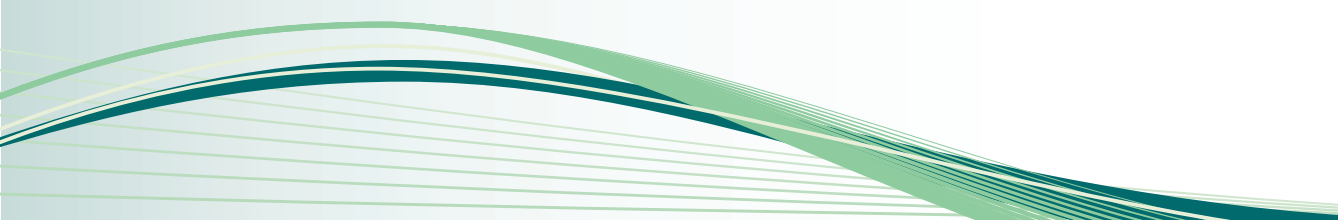

\section{Ana Roberta Vilarouca da Silva'}

Keywords

Hypertension; Prevalence; Adolescent; Risk factors; Schools; Pediatric nursing

Descritores

Hipertensão; Prevalência; Adolescente; Fatores de risco; Instituições acadêmicas; Enfermagem pediátrica

Submitted
September 29, 2014
Accepted
October 30, 2014

Corresponding author

Ana Roberta Vilarouca da Silva

Cícero Eduardo street, 905, Picos, PI,

Brazil. Zip Code: 64600-000

vilarouca@ufpi.edu.br

DOI

http://dx.doi.org/10.1590/1982-

0194201500014

\section{Abstract}

Objective: To assess the prevalence of arterial hypertension and the risk factors associated with it among adolescents.

Methods: Cross-sectional study developed with 211 adolescent students. The prevalence of arterial hypertension was assessed and its relationship with weight excess, physical activity and capillary glucose was verified.

Results: The prevalence of arterial hypertension was $13.7 \%$. No association was found between high blood pressure and weight excess and levels of physical activity. Adolescents with high capillary glucose presented greater chances of developing arterial hypertension.

Conclusion: The studied adolescents presented a high prevalence of arterial hypertension. The cases of hypertension were only associated with high capillary glucose.

\section{Resumo}

Objetivo: Avaliar a prevalência de hipertensão arterial e fatores de risco associados entre adolescentes. Métodos: Estudo transversal realizado com 211 adolescentes escolares. Foi avaliada a prevalência de hipertensão arterial e verificada a relação desta com o excesso de peso, atividade física e glicemia capilar. Resultados: A prevalência de hipertensão arterial foi de 13,7\%. Não foram observadas associações da pressão arterial elevada com o excesso de peso e níveis de atividade física. Os adolescentes com glicemia capilar elevada apresentaram maiores chances de desenvolver a hipertensão arterial.

Conclusão: Os adolescentes apresentaram elevada prevalência de hipertensão arterial. Os casos de hipertensão foram associados apenas com a glicemia capilar elevada.
'Universidade Federal do Piauí, Picos, PI, Brazil.

Conflicts of interest: there are no conflicts of interest to declare. 


\section{Introduction}

Systemic arterial hypertension is considered a global public health problem, causing 9.4 million deaths every year worldwide. ${ }^{(1)}$ This disorder has a multifactorial etiology, characterized by a persistent elevation of the blood pressure and by metabolic alterations, leading to the risk of cardiovascular complications. $^{(2)}$

The prevalence of systemic arterial hypertension has been increasing in developing countries, due to the fact that it is asymptomatic in its initial stages. In addition to this, the lack of information by part of the population contributes to its low control, ${ }^{(3)}$ affecting not only older adults, but also subjects in increasingly earlier age ranges.

In adolescence, arterial pressure alterations constitute an important risk factor for the development of arterial hypertension. ${ }^{(4)}$ Moreover, young adults who manifest high pressure levels tend to keep this condition as adults. Hence, it is important to evaluate the factors contributing to this situation and to promote subsidies for interventions. ${ }^{(5)}$

The investigation of risk factors for cardiovascular diseases, without involving laboratorial analyses, can represent a useful method, mainly as an alternative in places with few resources. ${ }^{(6)}$ In this context, the early identification of altered pressure levels is found as an essential tool for reducing the development of these diseases.

Therefore, the objective of this study was to assess the prevalence of arterial hypertension and its risk factors among adolescent students.

\section{Methods}

Cross-sectional research conducted in two public schools, located in the Northeast region of Brazil. The population was made of 500 students from the elementary education and the national acceleration program of youth and adult education in the schools mentioned. Sample size was calculated by means of a formula for finite populations, considering the level of confidence of 95\%, sampling error of $5 \%$, population size and prevalence. The sample was made of 211 students of both genders. Participants were selected by convenience, complying with the criteria established for eligibility.

Inclusion criteria were: being enrolled in the schools mentioned and being in the age range between 12 and 18 years. Students with a confirmed diagnosis of a chronic disease or other pathologies that would interfere directly in arterial pressure values or in obtaining anthropometric measures were excluded.

The instrument used for data collection was a semi-structured questionnaire involving sociodemographic characteristics (gender, age, education modality), anthropometric data (weight, height, body mass index, abdominal circumference) and measures of arterial pressure and capillary glucose.

Arterial pressure was measured by means of the auscultatory method, using an aneroid sphygmomanometer properly calibrated and a binaural stethoscope. The circumference of the arm of each participant was considered to choose the appropriate cuff. (7) The procedure for measuring the arterial pressure was performed with the subject sitting, after three to five minutes of rest, with the cuff placed at the heart level. ${ }^{(7)}$ Three measurements were made with a one-minute interval between each verification, the mean obtained in the last two measurements was considered. The arterial pressure was classified observing the participant's gender, age and height percentile. The adolescents who reached systolic and diastolic arterial pressure levels $\geq 95$ percentile were considered with arterial hypertension. ${ }^{(8)}$ For participants aged 18 years, arterial hypertension was defined when systolic arterial pressure values were $\geq 140 \mathrm{mmHg}$ and/or diastolic arterial pressure levels were $\geq 90 \mathrm{mmHg}$. ${ }^{(9)}$

Regarding anthropometric variables, the weight was obtained with the subject wearing light clothes and no shoes, using a portable scale with accuracy of $0.1 \mathrm{~kg}$ and capacity up to $150 \mathrm{~kg}$. Height was measured with a measuring stick, with accuracy of $0.5 \mathrm{~cm}$, vertically fixed on a flat wall. Based on the weight and height, the body mass index was calculated and the participants were classified according to their age and gender. ${ }^{(10)}$ The abdominal circumference was measured using a flexible and inelastic 
measuring stick, with a $0.5 \mathrm{~cm}$ scale, placed between the participant's inferior part of the last rib and the iliac crest, with no pressure, and measurement was classified according to specific cut-off points for adolescents. ${ }^{(11)}$

Capillary glucose measurements were performed at random, using properly calibrated OnCall Plus ${ }^{\oplus}$ glucometers, and the values obtained were interpreted according to the American Diabetes Association criteria. ${ }^{(12)}$ Regarding physical activity, students were considered to be active when they exercised for 30 minutes, at least three times a week. ${ }^{(13)}$

Data processing and statistical analysis were performed using the program Statistical Package for the Social Science ${ }^{\oplus}$, version 18.0. Quantitative variables were presented by means of descriptive statistics (mean and standard deviation), whereas qualitative variables were presented in the form of proportion, with a confidence interval of $95 \%$. Initially, the Kolmogorov-Smirnov test was applied to assess the normality of the quantitative variables. Student's $t$ test was used for independent samples, to analyze the difference between the means. Pearson's chi square test was applied to verify the association among the variables, and its effect was measured by means of the odds ratio, considering a level of significance of $\mathrm{p}<0.05$.

The development of this study complied with national and international ethical guidelines for research involving human subjects.

\section{Results}

A total of 211 adolescents of both genders were assessed, with $59.7 \%$ of them being female. The participants were aged between 12 and 18 years, with a mean of 14.4 years $( \pm 1.85)$. Regarding the classification of students by modality of education, $78.8 \%$ were in elementary school.

The characteristics of the studied population as for the analyzed variables are described in table 1. Male adolescents had higher levels of capillary glucose when compared to female participants $(\mathrm{p}<0.05)$.
Table 1. Characteristics of the studied variables in adolescents, according to gender

\begin{tabular}{lcccccc}
\hline \multirow{2}{*}{ Variable } & \multicolumn{2}{c}{ Male } & \multicolumn{2}{c}{ Female } & \\
& Mean & $\begin{array}{c}\text { Standard } \\
\text { deviation }\end{array}$ & Mean & $\begin{array}{c}\text { Standard } \\
\text { deviation }\end{array}$ & p-value* \\
\hline Age (years) & 14.3 & 1.7 & 14.4 & 1.9 & 0.628 \\
Body mass index $\left(\mathrm{kg} / \mathrm{m}^{2}\right)$ & 19.3 & 2.8 & 20.1 & 3.4 & 0.080 \\
Abdominal circumference $(\mathrm{cm})$ & 71.5 & 8.0 & 72.9 & 8.8 & 0.254 \\
Systolic arterial pressure $(\mathrm{mmHg})$ & 109.8 & 10.8 & 107.3 & 9.9 & 0.091 \\
Diastolic arterial pressure $(\mathrm{mmHg})$ & 72.1 & 10.2 & 71.2 & 8.2 & 0.502 \\
Capillary glucose $(\mathrm{mg} / \mathrm{dl})$ & 104.0 & 14.0 & 99.2 & 12.7 & 0.012 \\
\hline
\end{tabular}

*Student's t test for independent samples.

The prevalence of arterial hypertension in the entire group was $13.7 \%$ (confidence interval of 95\%: 9.1-18.4) (Figure 1).

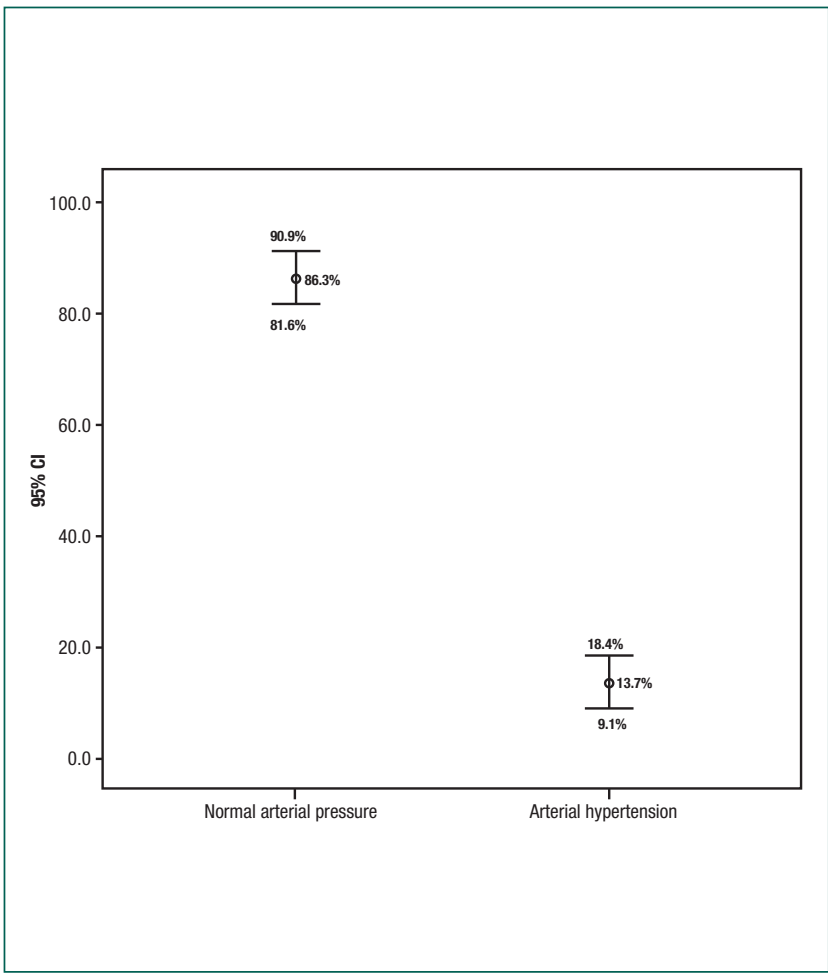

Figure 1. Prevalence of arterial hypertension in the studied population

Table 2 presents the analysis of the association between the cases of systemic arterial hypertension and the independent variables. No associations were observed between high arterial pressure and weight excess and levels of physical activity ( $>>0.05)$. However, adolescents with high capillary glucose presented greater chances (odds ratio: 4.6; confidence interval of $95 \%$ : 1.6-12.7) of developing systemic arterial hypertension. 
Table 2. Systemic arterial hypertension and its association with the studied variables

\begin{tabular}{|c|c|c|c|c|}
\hline Variables & $\begin{array}{c}\text { Normal arterial pressure } \\
\mathrm{n}(\%)\end{array}$ & $\begin{array}{c}\text { Arterial hypertension } \\
\mathrm{n}(\%)\end{array}$ & $\begin{array}{c}\text { Odds ratio } \\
\text { (Confidence interval of 95\%) }\end{array}$ & $p$-value* \\
\hline Gender & & & & 0.345 \\
\hline Male & $71(39.0)$ & $14(48.3)$ & & \\
\hline Female & $111(61.0)$ & $15(51.7)$ & $1.5(0.7-3.2)$ & \\
\hline Body mass index & & & & 0.727 \\
\hline Normal & $159(87.4)$ & $26(89.7)$ & & \\
\hline Weight excess & 23(12.6) & $3(10.3)$ & $0.8(0.2-2.9)$ & \\
\hline Abdominal circumference & & & & 0.484 \\
\hline Normal & $147(80.8)$ & $25(86.2)$ & & \\
\hline High & $35(19.2)$ & $4(13.8)$ & $0.7(0.2-2.1)$ & \\
\hline Glucose & & & & 0.002 \\
\hline Normal & $170(93.4)$ & 22(75.9) & & \\
\hline High & $12(6.6)$ & $7(24.1)$ & $4.6(1.6-12.7)$ & \\
\hline Physical activity & & & & 0.863 \\
\hline Active & $91(50.0)$ & $15(51.7)$ & & \\
\hline Sedentary & $91(50.0)$ & $14(48.3)$ & $1.1(0.5-2.5)$ & \\
\hline
\end{tabular}

*Pearson's chi square test

\section{Discussion}

The limitations of the results of this study are related to its cross-sectional design, which does not allow to determine cause and effect relationships among the studied variables.

The results presented contribute to reveal the prevalence and identify the risk factors associated with arterial hypertension in the studied group. These findings support the planning of interventions, in the nursing practice, aimed at the control of factors that contribute to the development of arterial hypertension in young groups.

The prevalence of systemic arterial hypertension $(13.74 \%)$ found in this study was considered high when compared to that expected for adolescents. ${ }^{(14,15)}$ In general, studies developed with this age group have revealed diverging prevalences. A population-based study showed that only $6.3 \%$ of the studied adolescents were classified with arterial hypertension. ${ }^{(16)}$ On the other hand, another study reached a percentage of $26.4 \%$. ${ }^{(17)}$ These variations may be related to the differences in the age range of the subjects and to the criteria used to define arterial hypertension.

As observed, high body mass indices did not present an association with systemic arterial hypertension in the adolescents of the present study. Although the literature provides mechanisms to support a relationship between obesity and increased pressure levels, ${ }^{(18)}$ other studies did not evidence an association of this variable with chances of developing systemic arterial hypertension in this group either. ${ }^{(19,20)}$ Moreover, weight excess seems to have a paradoxical effect in individuals with systemic arterial hypertension and other cardiovascular diseases, showing a protective function in the conditions of morbidity and mortality of these patients. ${ }^{(21,22)}$

Regarding the lifestyle of the adolescents, no relationship was found between levels of physical activity and cases of systemic arterial hypertension. In agreement with this finding, a population-based study developed with subjects aged between 15 and 19 years did not find an association of this variable with systemic arterial hypertension for both genders. ${ }^{(20)}$ However, considering the existence of different methods to assess the practice of physical activity, these findings should be carefully interpreted.

In the present study, the cases of systemic arterial hypertension were found significantly associated with capillary glucose alterations in the adolescents. In a study developed with adults with systemic arterial hypertension, the group classified with hypertension presented greater glucose means when compared to the control group $(101.62 \mathrm{mg} / \mathrm{dL}$ vs $82.46 \mathrm{mg} / \mathrm{dL}) .{ }^{(23)}$ In general, patients with systemic 
arterial hypertension are at risk of developing comorbidities, such as diabetes. In the case of young adults, in particular, arterial pressure alterations are strongly related to insulin resistance, ${ }^{(24)}$ which may have contributed to the glucose alteration found in this study.

\section{Conclusion}

The adolescents of the present study presented an increased prevalence of arterial hypertension. Weight excess and levels of physical activity were not associated with arterial pressure alterations. Adolescents with high capillary glucose presented greater chances of developing systemic arterial hypertension.

\section{Collaborations}

Moura IH and Silva ARV contributed to the project conception and data analysis and interpretation. Vieira EES; Silva GRF; Carvalho RBN and Silva ARV contributed to write the article and to critically review its intellectual content. Moura IH, Vieira EES and Silva ARV collaborated with the final approval of the version to be published.

\section{References}

1. Lim SS, Vos T, Flaxman AD, Danaei G, Shibuya K, Adair-Rohani H, AlMazroa MA, et al. A comparative risk assessment of burden of disease and injury attributable to 67 risk factors and risk factor clusters in 21 regions, 1990-2010: a systematic analysis for the Global Burden of Disease Study 2010. Lancet. 2012; 380:2224-60. Erratum in: Lancet. 2013; 381(9874):1276. Erratum in: Lancet. 2013; 381(9867):628. AlMazroa, Mohammad A [added]; Memish, Ziad A [added].

2. World Health Organization (WHO). Cardiovascular disease. A global brief on hypertension: silent killer, global public health crisis [Internet]. Geneva: WHO; 2013[cited 2014 Jul 18]. Available from: http:// www.who.int/cardiovascular_diseases/publications/global_brief_ hypertension/en.

3. Ibrahim MM, Damasceno A. Hypertension in developing countries. Lancet. 2012; 380(9859):611-9.

4. Redwine KM, Acosta AA, Poffenbarger T, Portman RJ, Samuels J. Development of Hypertension in Adolescents with Pre-Hypertension. J Pediatr 2012; 160(1):98-103.

5. McCrindle BW. Assessment and management of hypertension in children and adolescents. Nat Rev Cardiol. 2010; 7(3):155-63.

6. Pandya A, Weinstein MC, Gaziano TA. A comparative assessment of non-laboratory-based versus commonly used laboratory-based cardiovascular disease risk scores in the NHANES III population. PLOS ONE. 2011; 6(5):e20416.

7. Pickering TG, Hall JE, Appel LJ, Falkner BE, Graves J, Hill MN, Jones DW, Kurtz T, Sheps SG, Roccella EJ; Subcommittee of Professional and Public Education of the American Heart Association Council on High Blood Pressure Research. Recommendations for blood pressure measurement in humans and experimental animals: Part 1: blood pressure measurement in humans: a statement for professionals from the Subcommittee of professional and public education of the American heart association council on high blood pressure research. Hypertension. 2005; 45(1):142-161.

8. National High Blood Pressure Education Program Working Group on Hypertension Control in Children and Adolescents. The fourth report on the diagnosis, evaluation, and treatment of high blood pressure in children and adolescents. Pediatrics. 2004; 114(2 Suppl 4th Report):555-76.

9. Bakris GL, Black HR, Cushman WC, Green LA, Izzo JL Jr, Jones DW, Materson BJ, Oparil S, Wright JT Jr, Roccella EJ; National Heart, Lung, and Blood Institute Joint National Committee on Prevention, Detection, Evaluation, and Treatment of High Blood Pressure; National High Blood Pressure Education Program Coordinating Committee. The Seventh Report of the Joint National Committee on Prevention, Detection, Evaluation, and Treatment of High Blood Pressure: the JNC 7 report. JAMA. 2003; 289(19):2560-71.

10. Cole TJ, Bellizzi MC, Flegal KM, Dietz WH. Establishing a standard definition for child overweight and obesity worldwide: international survey. BMJ. 2000; 320(7244):1240-3.

11. Taylor RW, Jones IE, Williams SM, Goulding A. Evaluation of waist circumference, waist-to-hip ratio, and the conicity index as screening tools for high trunk fat mass, as measured by dual-energy X-ray absorptiometry, in children aged 3-19 y. Am J Clin Nutr. 2000; 72(2):490-5.

12. American Diabetes Association. Standards of medical care in diabetes-2013. Diabetes Care. 2013; 36 (Supl. 1):11-66.

13. World Health Organization (WHO). Report of a WHO. Consultation Group on Obesity. Obesity: preventing and managing the global epidemic. Geneva: WHO; 2000 .

14. Falkner B. Hypertension in children and adolescents: epidemiology and natural history. Pediatr Nephrol. 2010; 25(7):1219-24.

15. Flynn JT, Falkner BE. Obesity Hypertension in adolescents: epidemiology, evaluation, and management. J Clin Hypertens (Greenwich). 2011; 13(5):323-31.

16. Lu Q, Ma CM, Yin FZ, Liu BW, Lou DH, Liu XL: How to simplify the diagnostic criteria of hypertension in adolescents. J Hum Hypertens 2011; 25:159-63.

17. Zhou P, Chaudhari RS, Antal Z. Gender differences in cardiovascular risks of obese adolescents in the bronx. J Clin Res Pediatr Endocrinol 2010; 2(2):67-71.

18. Becton LJ, Shatat IF, Flynn JT. Hypertension and obesity: epidemiology, mechanisms and clinical approach. Indian J Pediatr 2012; 79(8):105661.

19. Hujova Z, Lesniakova M. Anthropometric risk factors of atherosclerosis: differences between urban and rural east-Slovakian children and adolescents. Bratisl Lek Listy. 2011; 112(9):491-6.

20. Aounallah-Skhiri H, El Ati J, Traissac P, Ben Romdhane H, EymardDuvernay S, Delpeuch F, et al. Blood pressure and associated factors in a north African adolescent population. A national cross-sectional study in Tunisia. BMC Public Health. 2012; 12:98. 
21. Uretsky S, Messerli FH, Bangalore S, Champion A, Cooper-Dehoff RM, Zhou Q, et al. Obesity paradox in patients with Hypertension and coronary artery disease. Am J Med. 2007; 120(10):863-70.

22. Van der GraafY, Visseren FL, Spiering W; SMART study group.The prevalence of obesity-related hypertension and risk for new vascular events in patients with vascular diseases. Obesity (Silver Spring). 2012; 20(10):2118-23.
23. Kumar NL, Deepthi J, Rao YN, Deedi MK. Study of lipid profile, serum magnesium and blood glucose in hypertension. Biol Med. 2010; 2:6-16

24. Torrance B, McGuire KA, Lewanczuk R, McGavock J. Overweight, physical activity and high blood pressure in children: a review of the literature. Vasc Health Risk Manag. 2007; 3(1):139-49. 